\title{
Media Bantu Berbasis Android untuk Perhitungan Harta Waris Secara Syariat Islam
}

\author{
Ira Puspitasari dan Mohammad Isa Irawan \\ Departemen Matematika, Fakultas Matematka dan Ilmu Pengetahuan Alam, Institut Teknologi \\ Sepuluh Nopember (ITS) \\ e-mail: m.isa.irawan@gmail.com
}

\begin{abstract}
Abstrak-Indonesia merupakan salah satu Negara dengan jumlah penduduk terbesar didunia. Hampir $85 \%$ dari jumlah penduduk Indonesia adalah umat beragama islam. Salah satu permasalahan yang dihadapi sebagian besar penduduk Indonesia khususnya yang beragama islam adalah permasalahan pembagian harta waris . Banyak orang islam yang tidak menggunakan lagi sistem pembagian waris menurut syaria'at islam sehingga persoalan waris sering sekali menjadi pemicu pertikaian yang menimbulkan keratakan hubungan kelurga. Disisi lain saat ini teknologi yang sedang trend adalah teknologi android. Hampir setiap orang memiliki handphone yang berbasis android. Android sendiri adalah suatu sistem operasi yang berjalan pada smatphone dan menyesuaikan spesifikasi dari kelas low-end hingga high-end Hampir semua vendor saat ini mengembangkan produknya dengan sistem operasi Android karena peminatnya yang semakin meningkat tajam. Berdasarkan permasalahan dan kondisi diatas maka dibuatlah sebuah alat bantu berbasis android untuk menyelesaikan perhitungan pembagian harta waris sesuai syariat islam yang dapat membantu menyelesaikan permasalahan yang dihadapi masyarakat diatas.
\end{abstract}

Kata Kunci-Android, Aplikasi, Smartphone, Syariat Islam, Sistem Operasi, Waris.

\section{PENDAHULUAN}

SEIRING dengan kemajuan teknolgi yang berkembang

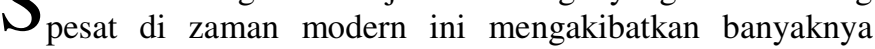
muncul produk-produk maupun jasa-jasa yang memanfaatkan tenologi yang mana teknologi tersebut berguna memudahkan manusia dalam memecahkan berbagai masalahnya. Di sisi lain masalah dalam masyarakat terus berkembang sehingga dibutuhkan beragam solusi untuk memecahkan masalah tersebut. Salah satu masalah yang dihadapi masyarakat khususnya masyarakat Indonesia yang mana sebagian besar penduduknya beragama islam yaitu sebesar $85 \%$ dari total penduduk di Indonesia adalah permasalahan tentang pembagian harta warisan. Banyak dijumpai kasus- kasus yang berujung pada meja hijau karena kasus pembagian waris tersebut. Ada kalanya bentuk-bentuk permasalahan warisan adalah perebutan harta waris oleh sanak saudara mayit karena ingin mendapatkan bagian harta waris lebih banyak dari bagian yang seharusnya. Padahal jika mau menilik dari kitab pedoman umat islam disebutkan bahwa semua ahli waris sudah memiliki bagian-bagiaannya sendiri.

Banyak sekali alasan mengapa orang Islam enggan atau malas untuk membagikan harta waris mereka dengan cara yang telah diatur oleh syariat Islam diantaranya adalah:
1. Kebanyakan Orang Islam belum memahami bagaimana cara pembagian harta waris yang benar menurut syariat Islam.

2. Cara pembagian harta waris menurut syariat Islam yang cukup rumit.

3. Jarangnya para ahli ilmu faraidh (waris).

Di sisi lain saat ini teknologi yang sedang trend adalah teknologi android. Hampir setiap orang memiliki handphone yang berbasis android. Android sendiri adalah suatu sistem operasi yang berjalan pada smatphone dan menyesuaikan spesifikasi dari kelas low-end hingga high-end. Hampir semua vendor saat ini mengembangkan produknya dengan sistem operasi Android karena peminatnya yang semakin meningkat tajam.

Dengan adanya teknologi android yang sedang berkembang pesat ini penulis ingin membuat sebuah aplikasi mengenai perhitungan pembagian harta waris sesuai syariat Islam yang netral dimana tidak memihak pada ahli waris tertentu dan hanya berpedoman dengan al quran dan al hadist yang shohih.Walaupun pada kenyataannya sudah banyak aplikasi android mengenai hukum waris namun tidak semuanya membahas mengenai perhitungan pembagian harta waris dan aplikasi yang sudah membahas perhitungan pembagian harta waris tidak semuanya mempu menyelsaikan permasalahan waris dengan benar khusunya kasus-kasus khusus yang terjadi dalam ahli waris seperti khasus saudara-kakek, kasus mukasamah, kasus akdariat, kasus mustarakah dan lai-lain.. Harapannya dengan aplikasi ini masyarakat khususnya masyarkat yang beragama islam di Indonesia dapat menyelesaikan permasalahan pembagian harta waris sesuai syariat islam baik kasus umum maupun kasus khusus dengan mudah dan cepat dan benar.

\section{METODE PENELITIAN}

\section{A. Study Literatur}

Pada tahap ini dilakukan pendalaman dan pembelajaran tentang ilmu yang akan digunakan dalam perancangan dan pembuatan suatu sistem. Pendalaman dan pembelajaran ilmu tersebut melalui buku faraidh, al quran , dan al hadist

\section{B. Analisa Sistem}

Pada Tahap analisa sistem ini dilakukan anlisa kebutuhankebutuhan yang diperlukan oleh sistem. Apabila ada kekurangan maka akan dilakukan perbaikan atas kekurangan dari program . Selain itu juga dilakukan penambahan fasilitas pada program bila dibutuhkan. 


\section{Desain Sistem}

Pada tahap desain sistem ini dilakukan pendesainan sistem secara konsep juga secara fisik.

\section{Pembuatan Program}

Pada tahap ini akan dilakukan pengaplikasian perhitungan waris ke dalam sistem android dan pengaplikasian desain yang telah dibuat ke dalam sistem android

\section{E. Pengujian Sistem}

Pada tahap ini dilakukan pengujian aplikasi oleh ahli ilmu faraid untuk mengetahui kebenaran sistem aplikasi ini dengan materi perhitungan waris yang ada . Adapun yang menguji adalah guru pondok pesantren khoirul huda Surabaya.

\section{F. Kesimpulaan}

Tahap akhir penelitian ini adalah penulisan laporan tugas akhir dan penarikan kesimpulan terhadap pembahasan yang telah dilakukan sebelumnya serta pemberian saran sebagai masukan untuk penelitian lebih lanjut

\section{ANALISIS DAN PEMBAHASAN}

\section{A. Ilmu Waris}

Ilmu waris merupakan salah satu ilmu dalam agama islam yang wajib dicari oleh umat islam. Dasar dalilnya yaitu sebagai berikut :

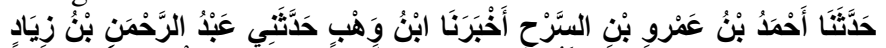

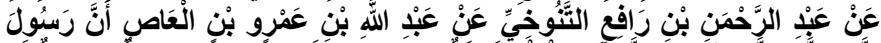

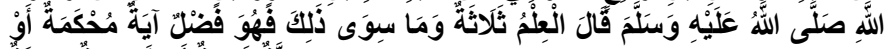

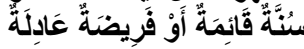

(ABUDAUD - 2499) : Telah menceritakan kepada kami [Ahmad bin 'Amr bin As Sarh], telah mengabarkan kepada kami [Ibnu Wahb] telah menceritakan kepadaku [Abdurrahman bin Ziyad] dari [Abdurrahman bin Rafi' At Tanukhi] dari[ Abdullah bin 'Amr bin Al 'Ash] bahwa Rasulullah adalah kelebihan yaitu: ayat muhkamah (yang jelas penjelasannya dan tidak dihapuskan), atau sunah yang shahih, atau faraidh (pembagian warisan) yang adil."

\section{B. Ahli Faraidh}

Ahli waris yang mempunyai bagian tertentu yaitu :

1. Anak perempuan

2. Cucu perempuan dari anak laki-laki

3. Ibu

4. Nenek dari jalur ibu

5. Nenek dari jalur bapak

6. Saudara perempuan sekandung

7. Saudara perempuan sebapak

8. Saudara laki-laki seibu

9. Saudara perempuan seibu

10. Suami

11. Istri

Sedangkan ahli waris yang tidak memilik bagian tertentu yaitu:

1. anak laki-laki

2. cucu laki-laki dari anak laki-laki

3. bapak

4. kakek dari jalur bapak
5. saudara laki-laki sekandung

6. Saudara laki-laki sebapak

7. Anak laki-laki dari saudara laki-laki sekandung

8. Anak laki-laki dari saudara laki-laki sebapak

9. Paman sekandung/ saudara laki-laki sekandungnya bapak

10. Paman sebapak/ saudara laki-laki sebapaknya bapak

11. Anak laki-laki paman sekandung

12. Anak laki-laki paman sebapak

13. Laki-laki atau perempuan yang memerdekakan budak

\section{Ashal Masalah (صل الدسا لة)}

Ashal masalah adalah bilangan terkecil yang bisa dibagi untuk semua bagian ahli waris sehingga masing-masing ahli waris mendapat bagian berupa bilangn bulat.

\section{Ashobah (عَصَبَُّة)}

Asobah adalah ahli waris yang tidak mendapat bagian tertentu. Mereka bisa menghabiskan seluruh harta warisan atau mendapat sisa harta warisan atau sama sekali tidak mendapat bagian.

\section{E. Bagian Ahli waris}

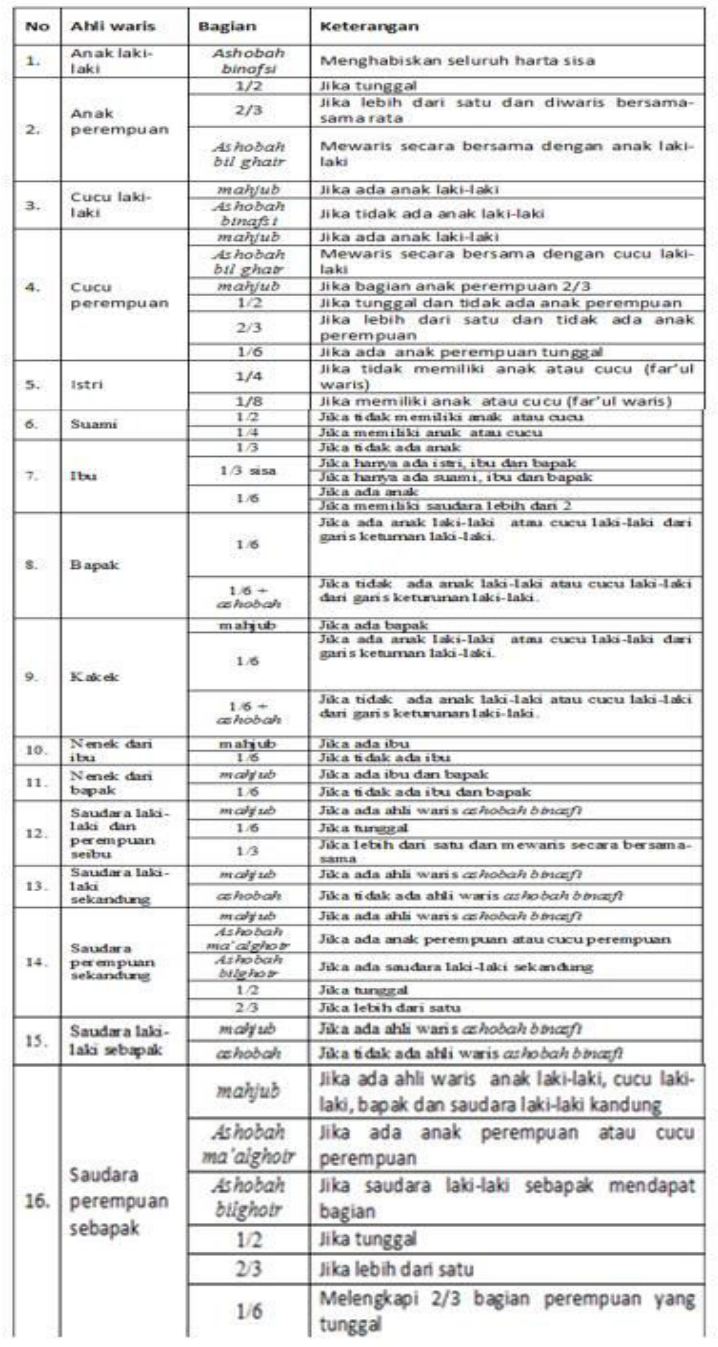

Gambar 1. Bagian ahli waris. 


\section{F. Android}

Android Studio adalah Lingkungan Pengembangan Terpadu - Integrated Development Environment (IDE) untuk pengembangan aplikasi Android, berdasarkan IntelliJ IDEA. Selain merupakan editor kode IntelliJ dan alat pengembang yang berdaya guna, Android Studio menawarkan fitur lebih banyak untuk meningkatkan produktivitas saat membuat aplikasi Android

\section{G. Use Case Diagram}

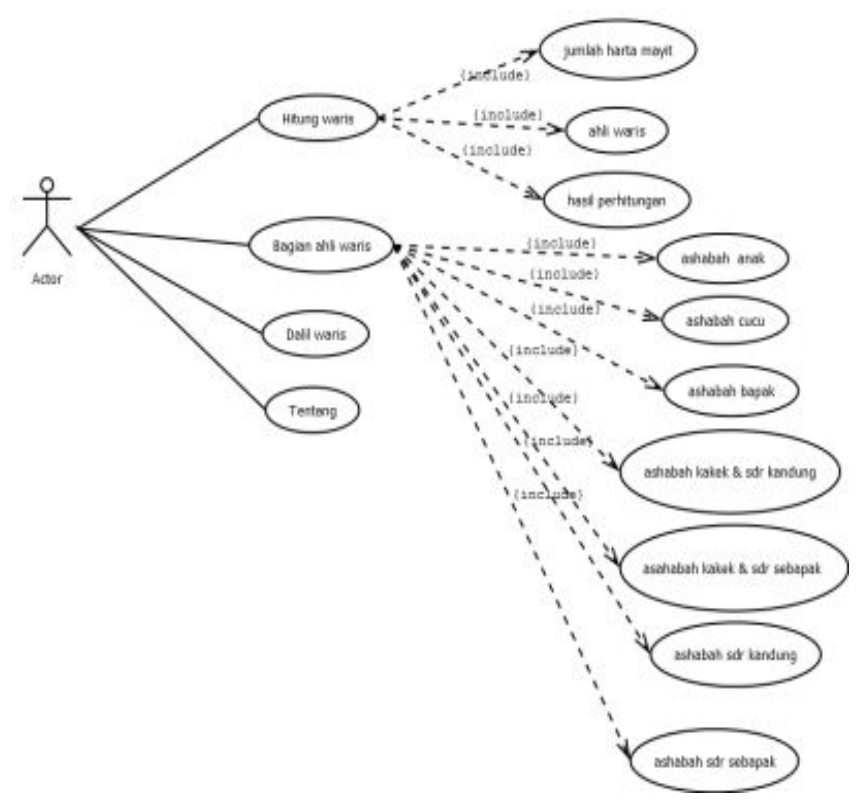

Gambar 2. Use case diagram aplikasi waris.

\section{H. Diagram Class}

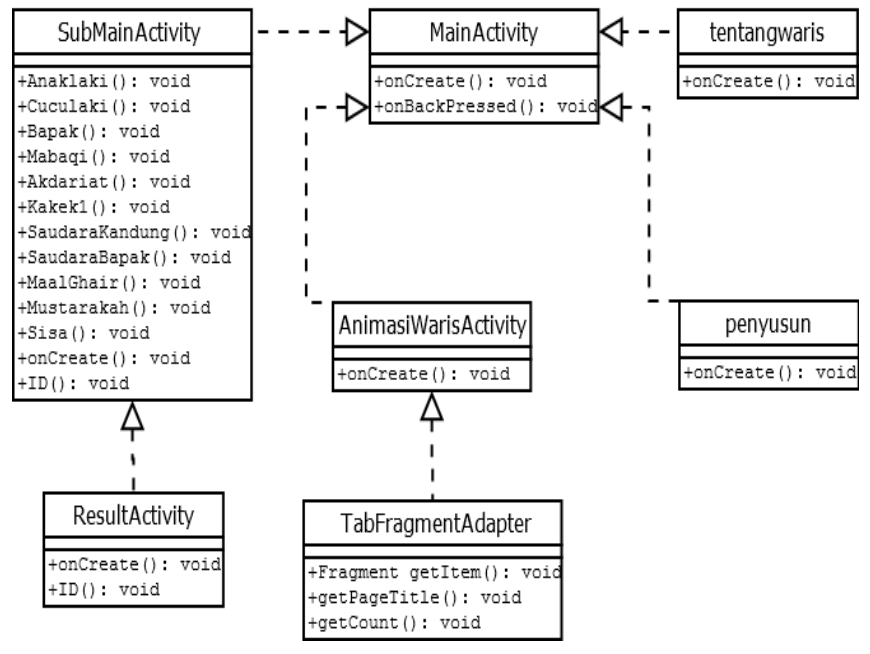

Gambar 3. Class diagram aplikasi waris.

\section{Sequence Diagram}

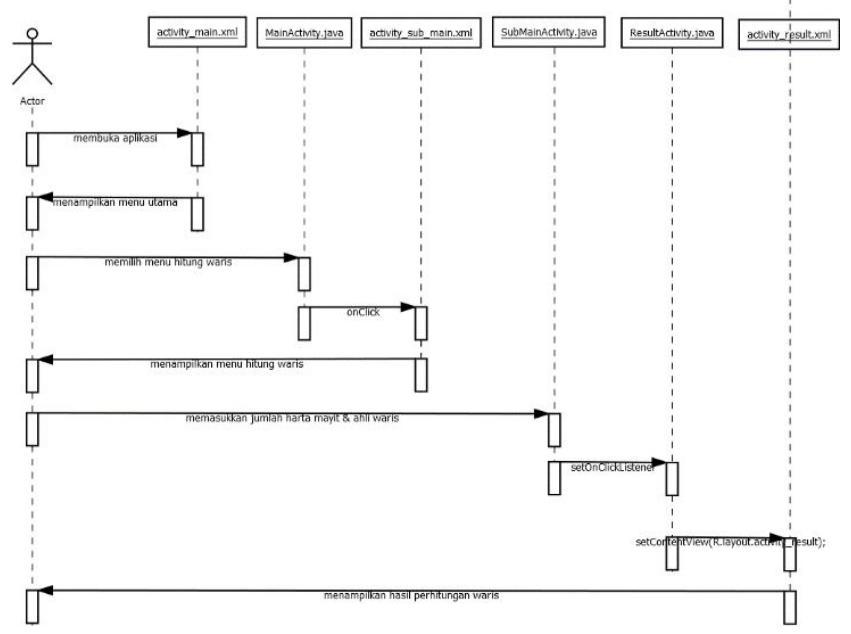

Gambar 4. Sequence diagram hitung waris.

\section{J. Activity Diagram}

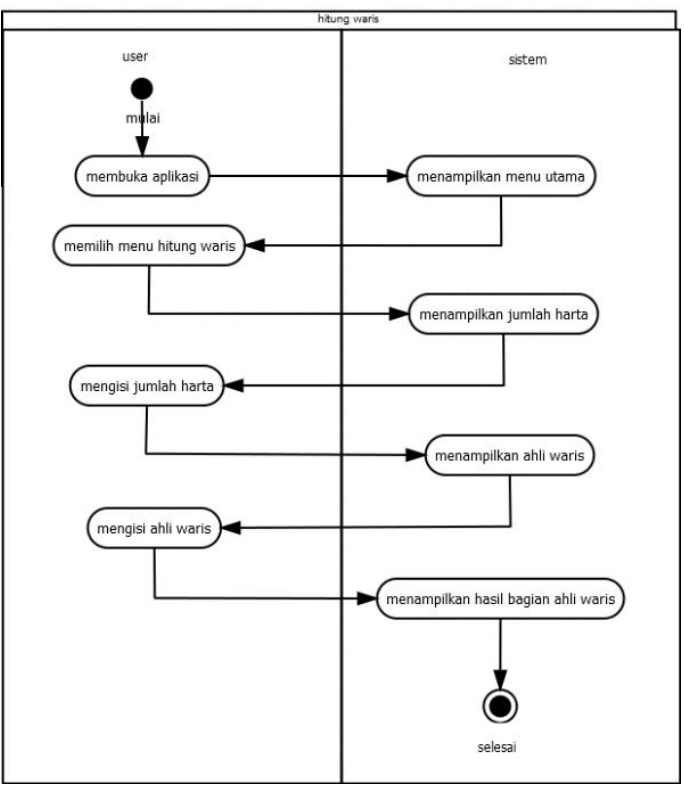

Gambar 5. Activity diagram hitung waris.

\section{K. Kasus Khusus Dalam Waris}

1. Kasus $1 / 3$ mabaqi

Ketika ibu hanya bersama bapak dan suami/istri maka ibu mendapat 1/3 sisa (البا قي) bukan 1/3 dari keseluruhan harta (جَمِنْ الما ل karena jika ibu mendapat bagian 1/3 dari seluruh harta maka ibu mendapat $1 / 3$ dan bapak mendapat 1/6. Dalam pembagian ini ibu mendapat bagian dua kali lipat bagian bapak, hal ini tidak sesuai dengan prinsip dasar hukum waris bahwa bagian laki-laki dua kali lipat bagian perempuan yang sederajat 


\begin{tabular}{l|ll}
\multicolumn{3}{c}{ Ashal Masalah : 6 } \\
\hline \hline Suami & $1 / 2$ & 3 \\
Ibu & $1 / 3$ & 2 \\
Bapak & Ashobah & 1 \\
\hline \hline \multicolumn{2}{|c}{} \\
\end{tabular}

Gambar 6. Perhitungan 1/3 Al Mabaqi.

\section{Penggabungan ('لمشتر كة)}

Apabila saudara sekandung bersama-sama dengan saudara seibu, sedangkan saudara seibu mendapat bagian dan saudara sekandung sebagai ahli waris ashobah tidak mendapat sisa bagian, maka saudara sekandung dalam pembagiannya digabungkan (المشتر كة) dengan saudara seibu dan mendapat bagian yang sama dengan bagian saudara seibu. Karena saudara sekandung dan saudara seibu sama-sama dilahirkan dari satu ibu.

\begin{tabular}{l|lllll} 
Ashal Masalah : $6 \times 5=30$ & \\
\hline \hline Suami & $1 / 2$ & 3 & 3 & 15 & 15 \\
Ibu & $1 / 6$ & 1 & 1 & 5 & 5 \\
Saudara perempuan seibu & & & & & 2 \\
Saudara laki-laki seibu & $1 / 3$ & 2 & & & 2 \\
Saudara laki-laki seibu & & & 2 & 10 & 2 \\
Saudara perempuan & & & & & 2 \\
sekandung & Ashobah & - & & & 2 \\
Saudara laki-laki sekandung & & & & \\
\hline \hline
\end{tabular}

Gambar 7. Perhitungan penggabungan.

\section{Akdariat}

Ada yang mengartikan akdariat adalah keruh atau kotor atau susah. Dinamakan demikian karena masalah tersebut menyusahkan Zaid ibnu tsabit. Karena hukum asli dari masalah kakek dan saudara perempuan ketika sisa harta hanya $1 / 6$ atau kurang dari 1/6 atau habis sama sekali maka saudara tidak mendapat warisan. Akan tetapi Zaid ibnu tsabit mengecualikan masalah ini, yaitu memberi bagian $1 / 2$ milik saudara perempuan sekandung atau sebapak dan $1 / 6$ milik kakek digabungkan dan dibagi bagian mukosamah satu banding dua.

Ashal Masalah: 6 Aul 9

\begin{tabular}{l|ll}
\hline \hline Suami & $1 / 2$ & 3 \\
Ibu & $1 / 3$ & 2 \\
Kakek & $1 / 6$ & 1 \\
Saudara perempuan sekandung/sebapak & $1 / 2$ & 3 \\
\hline \hline
\end{tabular}

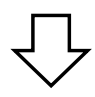

Ashal Masalah: 6 aul $9 \times 3=27$

\begin{tabular}{l|ccccc}
\hline \hline suami & $1 / 2$ & 3 & 3 & 9 & 9 \\
ibu & $1 / 3$ & 2 & 2 & 6 & 6 \\
kakek & $1 / 6$ & 1 & & & 8 \\
$\begin{array}{l}\text { Saudara perempuan } \\
\text { sekandung/sebapak }\end{array}$ & $1 / 2$ & 3 & 4 & 12 & 4 \\
\hline \hline
\end{tabular}

Gambar 8. Perhitungan Akdariat.

\section{Output Aplikasi}

\section{Tampilan Home}

Aplikasi ini memiliki tampilan home sebagai tampilan utama.Tampilan home ini merupakan tampilan yang berisi tombol-tombol yang terhubung ke dalam tampilan menu yang berkaitan dengan faraidh. Dalam tampilan ini terdapat tombol menu hitung waris, tombol menu bagian ahli waris, tombol menu dalil waris dan tombol menu tentang.

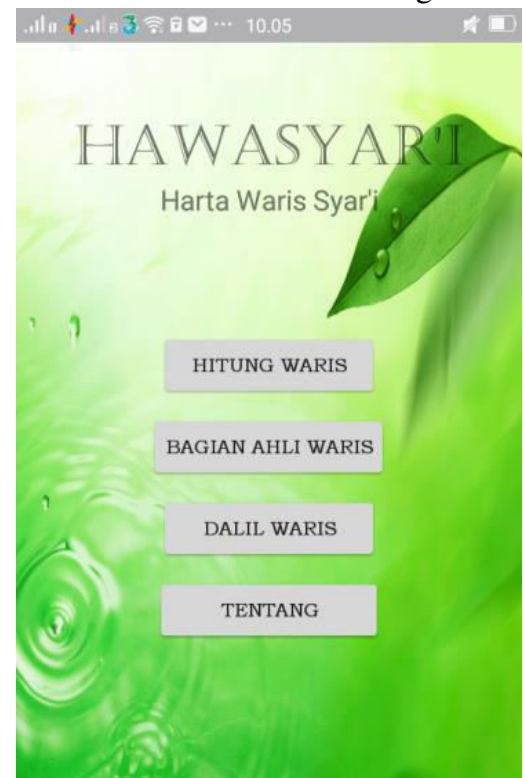

Gambar 9. Tampilan home.

\section{Tampilan Hitung Waris}

Dalam tampilan menu hitung waris pertama kali layar kan menampilkan pertanyaan jumlah harta yang ditinggalkan mayit. Disini pengguna dapat memasukkan angka tentang banyaknya jumlah harta yang ditinggalkan mayit tersebut.

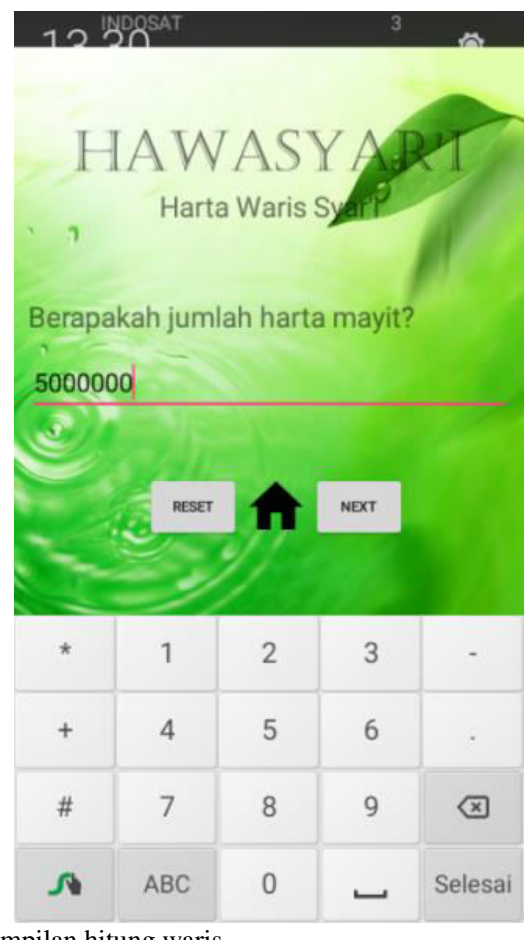

Gambar 10. Tampilan hitung waris. 


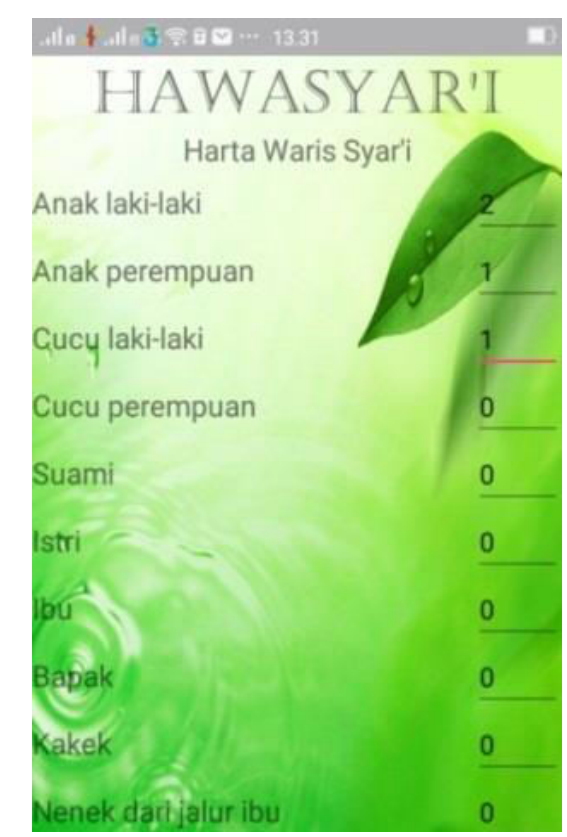

Gambar 11. Tampilan ahli waris

Pada tampilan ini terdapat ahli waris yang tersedia mulai jalur anak, cucu, orang tua, kakek nenek, suami, istri, hingga saudara baik saudara kandung, saudara seibu maupun saudara sebapak. Nilai awal untuk jumlah ahli waris adalah nol. Pengguna dapat mengubah nilai tersebut sesuai dengan kondisi jumlah ahli waris yang ada.

3. Perhitungan dan Tampilan Hasil Perhitungan

Pada kasus akdariat ini dimisalkan harta mayit sebesar Rp 27.000.000. Ahli waris pada kasus ini adalah hanya ada suami, ibu, kakek, saudari sekandung atau saudari sebapak. Maka perhitungan waris adalah sebagai berikut :

Ashal Masalah: 6 Aul 9

\begin{tabular}{l|ll}
\hline \hline Suami & $1 / 2$ & 3 \\
Ibu & $1 / 3$ & 2 \\
Kakek & $1 / 6$ & 1 \\
Saudara perempuan & $1 / 2$ & 3 \\
sekandung/sebapak & & \\
\hline \hline
\end{tabular}

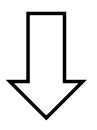

Ashal Masalah: 6 aul 9 × $3=27$

\begin{tabular}{l|cllll}
\hline Suami & $1 / 2$ & 3 & 3 & 9 & 9 \\
Ibu & $1 / 3$ & 2 & 2 & 6 & 6 \\
Kakek perempuan & $1 / 6$ & 1 & & & 8 \\
$\begin{array}{l}\text { Saudara } \\
\text { sekandung/sebapak }\end{array}$ & $1 / 2$ & 3 & 4 & 12 & 4 \\
\hline \hline
\end{tabular}

- Bagian harta suami

$$
\begin{aligned}
& =\frac{\text { bagian suami }}{\text { ashal masalah }} \times \text { jumlah harta } \\
& =\frac{9}{27} \times R p 27.000 .000=R p 9.000 .000
\end{aligned}
$$

- Bagian harta ibu

$$
=\frac{\text { bagian ibu }}{\text { ashal masalah }} x \text { jumlah harta }
$$

$$
=\frac{6}{27} \times R p 27.000 .000=R p 6.000 .000
$$

- Bagian harta kakek

- $=\frac{\text { bagian kakek }}{\text { ashal masalah }} x$ jumlah harta

$$
=\frac{8}{27} x R p 27.000 .000=R p 9.000 .000
$$

- Bagian harta saudari kandung

$$
\begin{aligned}
& =\frac{\text { bagian saudari kandung }}{\text { ashal masalah }} \times \text { jumlah harta } \\
& =\frac{4}{27} \times R p 27.000 .000=R p 4.000 .000
\end{aligned}
$$

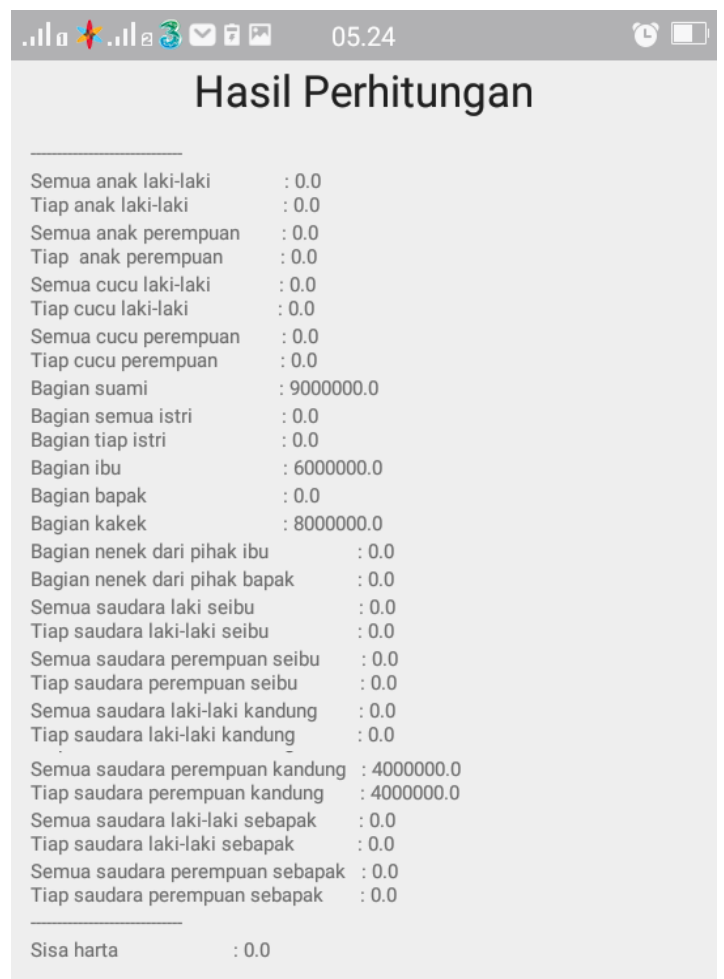

Gambar 12. Tampilan hasil perhitungan kasus akdaria

4. Menu Dalil Waris

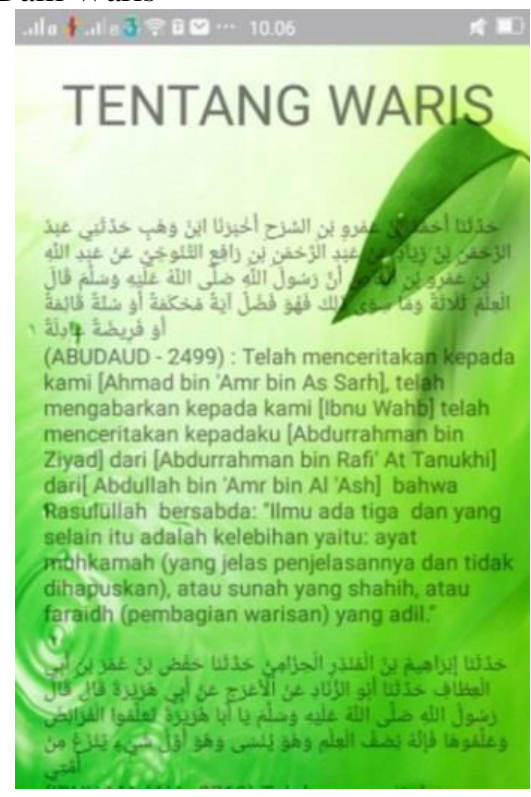

Gambar 13. Tampilan menu dalil waris. 
Pada tampilan ini terdapat referansi dallil yang berkaitan dengan faraid yang mana dalil tersebut dipetik dalil hadist shahih seperti hadis riwayat Abu Dawud, hadis riwayat Ibnu Majah, dan hadis riwayat Ad Darimi. Tujuan disertakan dalil ini adalah untuk memperkuat pemahaman tentang pentingnya memahami ilmu faraid. Dalam menu dalil waris ini terdapat 3 hadist mengenai faraid. Pengguna harus menscrollnya kebawah jika ingin melihat dalil tersebut secara keseluruhan.

\section{Menu Bagian Ahli Waris}

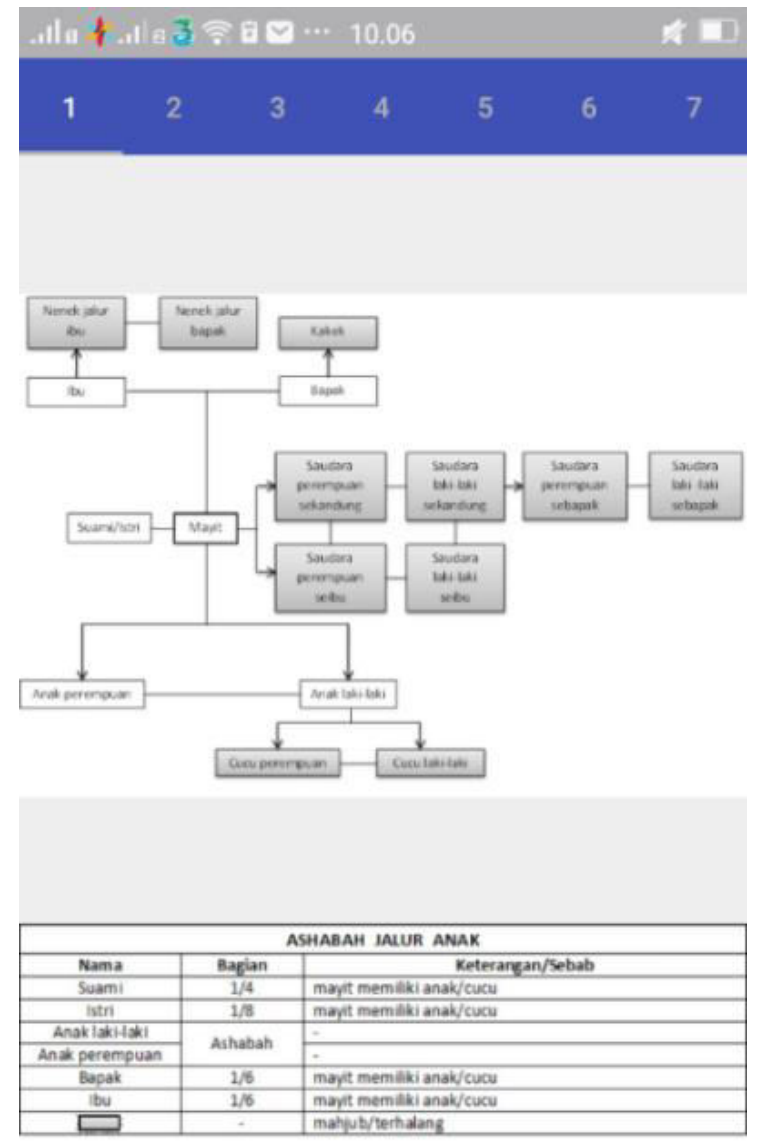

Gambar 14. Tampilan menu bagian ahli waris

Pada menu ini terdapat diagram susunan ahli waris. Ada 7 kasus yang mungkin terjadi dalam pembagian harta waris yang dapat dilihat pada menu ini. 7 kasus tersebut antara lain :

1. Ashabah jalur anak

2. Ashabah jalur cucu

3. Ashabah jalur bapak

4. Ashabah jalur kakek dan saudara kandung

5. Ashabah jalur kakek dan saudara sebapak

6. Ashabah jalur saudara kandung

7. Ashabah jalur saudara sebapak

6. Menu Keluar Aplikasi

Pada menu ini digambarkan pada gambar 5.11 user akan ditanyakan lagi apakah yakin ingin keluar dari aplikasi atau tidak.

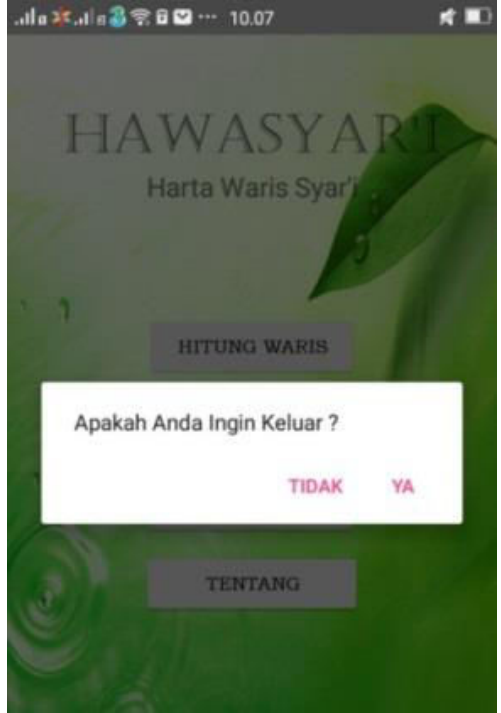

Gambar 15. Tampilan menu keluar

\section{KESIMPULAN DAN SARAN}

A. Kesimpulan

1. Aplikasi media pembelajaran berbasis android ini merupakan media yang berguna untuk membantu masyrakat dalam pemecahan masalah pembagian harta waris.

2. Melalui Aplikasi ini, dapat lebih memahami hakikat ilmu waris

3. Aplikasi ini hanya bisa dijalankan pada smartphone bersistem operasi android, selain dari sistem operasi android tidak dapat dijalankan.

\section{B. Saran}

1. Aplikasi pembelajaran ini masih dapat dikembangkan lagi dengan dilengkapi animasi bagian - bagian ahli waris supaya proses memahami faraidh lebih menarik.

2. Perlu kajian lebih lanjut mengenai perhitungan waris ini supaya perhitungan waris dengan media android ini bisa menghasilkan perhitungan yang akurat yang mana hasilnya sama jika dibandingkan perhitungan secara manual.

\section{DAFTAR PUSTAKA}

[1] H. Wahidah. 2014. Buku Ajar Fikh Waris. Banjarmasin: Iain Antasari Press.

[2] As-Sayyid Sabiq. 1988. "Fiqih Sunnah, FAROIDH (waris)". Jilid 14. Bandung: Alma'arif.

[3] Malik, Imam. 2002. "Muatol". Bairut Libanon: Darul Al Kotob Al Ilmiyah.

[4] Ir. Yuniar Supardi. 2011. "Sетиa Bisa Menjadi Programer Android Basic, Mengenal Java dan Android". Jakarta: Buku Exel Media Komputindo.

[5] Nugroho, Adi. 2004. "Pemograman Berorientasi Objek". Bandung: Penerbit Informatika.

[6] Safaat, Nazaruddin. 2012. "Pemograman Aplikasi Mobile Smartphone dan Tablet PC Berbasis Android". Bandung: Penerbit Informatika

[7] Athoillah, Muhammad; M Isa Irawan." Perancangan Sistem Informasi Mobile Berbasis Android Untuk Kontrol Persediaan Barang Di Gudang".Surabaya Jurnal Sains dan Seni Pomits.Vol. 1, No.1, (2013)16 